\title{
Potential of Maintaining a Healthy Vaginal Environment by Two Lactobacillus Strains Isolated from Cocoa Fermentation
}

\author{
Ana Clara Correia Melgaço, ${ }^{1}$ Wallace Felipe Blohem Pessoa, ${ }^{1}$ Herbert Pina Freire, ${ }^{1}$ \\ Milena Evangelista de Almeida $\left(\mathbb{D},{ }^{1}\right.$ Maysa Santos Barbosa, ${ }^{2}$ Rachel Passos Rezende, ${ }^{3}$ \\ Jorge Timenetsky, ${ }^{2}$ Lucas Miranda Marques $\mathbb{D}^{2,4}$ and Carla Cristina Romano ${ }^{1}{ }^{1}$ \\ ${ }^{1}$ Departamento de Ciências Biológicas, Laboratório de Imunologia, Centro de Biotecnologia e Genética, Universidade Estadual de \\ Santa Cruz (UESC), Campus Soane Nazaré de Andrade, Salobrinho, Rodovia Jorge Amado, Km 16, 45662-900 Ilhéus, BA, Brazil \\ ${ }^{2}$ Instituto de Ciências Biomédicas, Departamento de Microbiologia, Laboratório de Micoplasmas, Universidade de São Paulo (USP), \\ São Paulo, Brazil \\ ${ }^{3}$ Departamento de Ciências Biológicas, Laboratório de Biotecnologia Microbiana, Centro de Biotecnologia e Genética, \\ Universidade Estadual de Santa Cruz (UESC), Campus Soane Nazaré de Andrade, Salobrinho, Rodovia Jorge Amado, Km 16, \\ 45662-900 Ilhéus, BA, Brazil \\ ${ }^{4}$ Instituto Multidisciplinar em Saúde/Campus Anísio Teixeira, Universidade Federal da Bahia, IMS/CAT-UFBA, \\ Vitória da Conquista, Brazil
}

Correspondence should be addressed to Carla Cristina Romano; romanocc@uol.com.br

Received 16 June 2018; Revised 28 August 2018; Accepted 12 September 2018; Published 30 September 2018

Academic Editor: Frederick D. Quinn

Copyright (c) 2018 Ana Clara Correia Melgaço et al. This is an open access article distributed under the Creative Commons Attribution License, which permits unrestricted use, distribution, and reproduction in any medium, provided the original work is properly cited.

\begin{abstract}
Bacteria in the genera Mycoplasma and Ureaplasma do not have cell walls and therefore interact with host cells through lipidassociated membrane proteins (LAMP). These lipoproteins are important for both surface adhesion and modulation of host immune responses. Mycoplasma and Ureaplasma have been implicated in cases of bacterial vaginosis (BV), which can cause infertility, abortion, and premature delivery. In contrast, bacteria of the genus Lactobacillus, which are present in the vaginal microbiota of healthy women, are thought to inhibit local colonization by pathogenic microorganisms. The aim of the present study was to evaluate the in vitro interactions between lipoproteins of Mycoplasma and Ureaplasma species and vaginal lineage (HMVII) cells and to study the effect of Lactobacillus isolates from cocoa fermentation on these interactions. The tested Lactobacillus strains showed some important probiotic characteristics, with autoaggregation percentages of $28.55 \%$ and $31.82 \%$ for L. fermentum FA4 and L. plantarum PA3 strains, respectively, and percent adhesion values of 31.66 and $41.65 \%$, respectively. The two strains were hydrophobic, with moderate to high hydrophobicity values, $65.33 \%$ and $71.12 \%$ for L. fermentum FA 4 and L. plantarum PA3 in toluene. Both strains secreted acids into the culture medium with $\mathrm{pH}=4.32$ and $\mathrm{pH}=4.33$, respectively, and showed antibiotics susceptibility profiles similar to those of other lactobacilli. The strains were also able to inhibit the death of vaginal epithelial cells after incubation with U. parvum LAMP from $41.03 \%$ to $2.43 \%$ (L. fermentum FA4) and $0.43 \%$ (L. plantarum PA3) and also managed to significantly decrease the rate of cell death caused by the interaction with LAMP of $M$. hominis from $34.29 \%$ to $14.06 \%$ ( $L$. fermentum FA4) and $14.61 \%$ (L. plantarum PA3), thus demonstrating their potential for maintaining a healthy vaginal environment.
\end{abstract}

\section{Introduction}

Bacteria of the genera Mycoplasma and Ureaplasma belong to the class Mollicutes, and these microorganisms are the smallest known free-living organisms. With genomes of only $580-2,200 \mathrm{~kb}$, depending on the species, these bacteria contain only the minimal structures necessary for cell growth and replication and are unable to synthesize some substances that are essential for their growth. Therefore, these substances must be obtained from their hosts $[1,2]$. Because they do not have cell walls, these bacteria contact host cells through their plasma membrane, which is composed of a lipid-protein 
bilayer. Mycoplasmas lipid-associated membrane proteins (LAMP) play an important role in both adhesion to the host cell surface and immune response modulation through the production of proinflammatory cytokines. They also induce apoptosis in different types of cells, such as monocytes and macrophages [3-5]. Mycoplasmas and ureaplasmas are pathogens that are frequently associated with mucosal infections of the respiratory and urogenital tracts $[1,2]$. In the female genital tract, mycoplasmas and ureaplasmas have been directly implicated in cases of bacterial vaginosis (BV) $[6,7]$.

$\mathrm{BV}$ is a syndrome resulting from an imbalance of the vaginal microbiota, with concomitant proliferation of pathogenic bacteria. These infections mainly affect women of childbearing age, and they have been associated with infertility, preterm birth, endometritis, pelvic inflammatory disease, and susceptibility to infection with human immunodeficiency virus (HIV) $[6,8,9]$. In addition to Mycoplasma and Ureaplasma species, the other major bacterial species related to BV belong to the genera Chlamydia, Neisseria, and Gardnerella [10]. Vaginal microbiota is considered to be healthy when specific bacterial community types that have beneficial functions for the host are present, along with the absence of clinical symptoms [11]. The vaginal microbiota of symptom-less women generally includes species of the genus Lactobacillus; these bacteria produce lactic acid, hydrogen peroxide $\left(\mathrm{H}_{2} \mathrm{O}_{2}\right)$, bacteriocins, and hydroxyl radicals and thereby inhibit local colonization by pathogenic microorganisms. In addition, the presence of lactobacilli favors a protective environment for the fetus in pregnancy [10].

Lactobacilli as well as bacteria of the genus Bifidobacterium, Lactococcus lactis, and Escherichia coli as well as the yeast Saccharomyces cerevisiae have been used as probiotics, mainly by the food industry [12]. Probiotics are living microorganisms that, when administered in adequate quantities, confer benefits to host health [13]. Generally, lactobacilli in probiotic formulations were isolated from human microbiota; however, in recent years there has been growing interest in the use of strains isolated from nonhuman sources, including fermented foods, such as cocoa. Thus, in several studies, the probiotic potential of strains isolated from food fermentation has been investigated $[14,15]$. Studies previously conducted by our research group showed that Lactobacillus strains derived from the fermentation of cocoa exhibited probiotic potential and antibiotics activity against distinct pathogens. Different strains reduced histological damage and the systemic concentration of inflammatory cytokines and elevated serum levels of immunoglobulin A ( $\operatorname{IgA}$ ) in a model of experimental colitis [16]. Culture supernatants of L. fermentum TCUESC01 and L. plantarum TCUESC02 inhibited growth and reduced the biofilm formation ability of streptomycin- and dihydrostreptomycin-resistant strains of Staphylococcus aureus [17]. They also showed antagonistic activity against $G$. vaginalis [18]. The aim of this study was to evaluate the in vitro interaction of lipoproteins from genital human Mycoplasma and Ureaplasma species with the HMVII vaginal cell line and to study the effect of Lactobacillus on this interaction.

\section{Materials and Methods}

2.1. Cell Lines, Microorganisms, and Growth Conditions. HMVII human vaginal epithelial cell line (BCRJ 0316) was obtained from the Rio de Janeiro Cell Bank and was grown in RPMI 1640 medium, supplemented with 10\% fetal bovine serum (FSB), penicillin $100 \mathrm{IU} / \mathrm{mL}$, and streptomycin $100 \mu \mathrm{g} / \mathrm{mL}$.

L. fermentum FA4 and L. plantarum PA3 were previously isolated by our research group from a cocoa fermentation [16]. These strains were confirmed to the species level by $16 \mathrm{~S}$ rRNA sequencing and were deposited in GenBank (http://www.ncbi.nlm.nih.gov/) under accession numbers KU244506 and KU244472, respectively. Lactobacilli were grown in de Man, Rogosa, and Sharpe (MRS) medium for $18 \mathrm{~h}$ at $37^{\circ} \mathrm{C}$ in anaerobic jar.

M. hominis (ATCC 23114) and M. genitalium (ATCC 33530) were grown in $1 \mathrm{~L}$ of SP-4 medium. U. urealyticum serotype 7 (ATCC 27819) and U. parvum serotype 3 (ATCC 27815) were cultured in $200 \mathrm{~mL}$ of Ureaplasma Broth (UB) medium. All strains were maintained at $37^{\circ} \mathrm{C}$ and $5 \% \mathrm{CO}_{2}$ until log phase growth. Growth control was observed by the observation of color change in the liquid medium, plus $\mathrm{pH}$ indicator (phenol red).

2.2. Extraction of Membrane-Associated Lipoproteins (LAMP). Lipoproteins were extracted according to the method developed by Wang et al. [19] with some modifications. Briefly, M. hominis, M. genitalium, U. parvum, and U. urealyticum were cultured until log phase, until the observation of color change in the liquid medium, $\mathrm{pH}$ indicator (phenol red). Then, the cells were recovered by centrifugation at $23,700 \times g$ for $30 \mathrm{~min}$ at $4^{\circ} \mathrm{C}$ (Beckman Coulter) and washed with sterile phosphate-buffered saline (PBS) $(1 \mathrm{X}, \mathrm{pH} 7,4)$ to remove the residual culture medium. The cell pellet was suspended in $5 \mathrm{~mL}$ of Tris-EDTA (50 mM Tris [pH 8], $0.15 \mathrm{M} \mathrm{NaCl}, 1 \mathrm{mM}$ EDTA), and Triton TX-114 was added to a final concentration of $2 \%$. The mixture was homogenized by vortexing and incubated at $4^{\circ} \mathrm{C}$ for $60 \mathrm{~min}$. The lysate was then incubated at $37^{\circ} \mathrm{C}$ for $10 \mathrm{~min}$ and centrifuged at $23,700 \times g$ at $22^{\circ} \mathrm{C}$ for $20 \mathrm{~min}$ for phase separation. The upper aqueous phase was discarded, and in the final TX-114 step, the volume was adjusted to the original volume by the addition of Tris-EDTA. Then, 2.5 volumes of ethanol were added to precipitate the lipoproteins overnight at $-20^{\circ} \mathrm{C}$. The precipitated materials were recovered by centrifugation at $23,700 \times g$ for $15 \mathrm{~min}$ at $4^{\circ} \mathrm{C}$. After centrifugation, the pellet was homogenized in PBS by sonication, 6 to 8 cycles per minute at a power of $10 \mathrm{~W}$ (Coler-Parmer Ultrasonic Processor). Then, the microtubes containing the lipoproteins were stored at $-80^{\circ} \mathrm{C}$ until use. Lipoproteins were quantitated using the 2D Quant Kit (GE Healthcare) according to the manufacturer's protocol and preincubated for $2 \mathrm{~h}$ with polymyxin $\mathrm{B}$ at $1000 \mathrm{U} / \mathrm{mL}$ prior to the use.

2.3. Autoaggregation Assay. To verify the autoaggregation capacity of the Lactobacillus strains, the method of Kos et al. [20] was used, with some modifications. Briefly, the strains were cultured in MRS broth for $18 \mathrm{~h}$ at $37^{\circ} \mathrm{C}$ in anaerobic 
jar. Then, the cells were recovered by centrifugation (8000 $\times g, 10 \mathrm{~min}$ ), washed twice with $0.9 \%$ saline solution $(\mathrm{w} / \mathrm{v})$, and suspended in the same solution to $1 \times 10^{8} \mathrm{CFU} / \mathrm{mL}$ in a spectrophotometer (Thermo-Scientific). The suspensions were homogenized by vortexing and incubated at $37^{\circ} \mathrm{C}$ for $5 \mathrm{~h}$. Then, a $1 \mathrm{~mL}$ aliquot was gently removed from the top of the suspension every hour, and its absorbance at $600 \mathrm{~nm}$ $\left(\mathrm{A}_{600}\right)$ was read in a spectrophotometer (Thermo-Scientific). Autoaggregation was calculated using the following formula: autoaggregation $(\%)=\left[\left(\mathrm{A}_{0}-\mathrm{A}_{\mathrm{t}}\right) / \mathrm{A}_{0}\right] \times 100$, where $\mathrm{A}_{0}$ is the absorbance at time $0 \mathrm{~h}$, and At is the absorbance at time $\mathrm{t}$, which was measured every hour, for up to $5 \mathrm{~h}$.

2.4. Hydrophobicity Assay. The hydrophobicity of the Lactobacillus strains was verified by testing microbial adherence to hydrocarbons (MATH), using a method adapted from Rodríguez et al. [21]. Lactobacillus strains were cultured in MRS broth at $37^{\circ} \mathrm{C}$ for $18 \mathrm{~h}$ in anaerobic jar. Then, the cultures were harvested by centrifugation $(8000 \times g, 10 \mathrm{~min})$, washed twice with $0.9 \%$ saline, and adjusted to an optical density at $600 \mathrm{~nm}\left(\mathrm{OD}_{600}\right)$ of 0.7 in saline. One milliliter of solvent (xylene or toluene) was added to each bacterial suspension, and the mixtures were vortexed for $2 \mathrm{~min}$ and then incubated for $2 \mathrm{~h}$ at $37^{\circ} \mathrm{C}$. The lower aqueous phase was carefully removed, and the $A_{600}$ was read in a spectrophotometer. Hydrophobicity was calculated using the following formula: hydrophobicity $(\%)=\left(\left(\mathrm{A}_{0}-\mathrm{A}_{2}\right) / \mathrm{A}_{0}\right) \times 100$, where $\mathrm{A}_{0}$ is the absorbance at time $0(0 \mathrm{~h})$ and $\mathrm{A}_{2}$ is the absorbance after $2 \mathrm{~h}$.

2.5. Lactobacillus Adhesion to HMVII Cells. To verify the adhesion capacity of the Lactobacillus strains to HMVII cells, the method of Santos et al. [16] was used, with some modifications. Initially, a monolayer of HMVII cells at a concentration of $1 \times 10^{6}$ cells/well was grown in 24-well plates in an incubator (SANYO) at $37^{\circ} \mathrm{C}$ and $5 \% \mathrm{CO}_{2}$, and the lactobacilli were grown in MRS broth for $18 \mathrm{~h}$ at $37^{\circ} \mathrm{C}$ in anaerobic jar. After culture, the lactobacilli were recovered by centrifugation $(8000 \times g, 10 \mathrm{~min})$, washed twice with $0.9 \%$ saline solution (w/v), and adjusted to $10^{8} \mathrm{CFU} / \mathrm{mL}$ in RPMI supplemented with $10 \%$ fetal bovine serum (FBS). Lactobacillus suspensions were added to wells containing HMVII cells and were incubated for $2 \mathrm{~h}$ at $37^{\circ} \mathrm{C}$ and $5 \%$ $\mathrm{CO}_{2}$. Subsequently, the cells were washed three times with $0.9 \%$ saline solution $(\mathrm{w} / \mathrm{v})$ and removed from the plates with $0.25 \%$ trypsin-EDTA for $5 \mathrm{~min}$. The percentage of adhered lactobacilli was determined by plating serial dilutions on MRS agar. The plates were incubated for $48 \mathrm{~h}$ at $37^{\circ} \mathrm{C}$, and then the bacteria $(\mathrm{CFU} / \mathrm{mL})$ were counted. The percentage of adherent lactobacilli was calculated by the following formula: adhesion $(\%)=\left(\right.$ final $\left.\mathrm{CFU}_{\text {end }} / \mathrm{CFU}_{\text {initial }}\right) \times 100$.

To visualize the adhesion of the Lactobacillus strains to HMVII cells, scanning electron microscopy (SEM) was performed. HMVII cells $\left(1 \times 10^{6}\right.$ cells/well $)$ were grown on 24 -well plates (containing glass coverslips in each well) in an incubator (SANYO) at $37^{\circ} \mathrm{C}$ and $5 \% \mathrm{CO}_{2}$, with one of the two tested Lactobacillus strains $\left(1 \times 10^{8} \mathrm{CFU} / \mathrm{mL}\right)$ and incubated for $2 \mathrm{~h}$ at $37^{\circ} \mathrm{C}$ and $5 \% \mathrm{CO}_{2}$. HMVII cells alone were used as controls. After incubation, the coverslips were washed three times with $0.9 \%$ saline solution to remove the nonadherent lactobacilli cells.

2.6. Evaluation of Acid Production by Lactobacilli. To evaluate acid production by lactobacilli the method of Pessoa el al. was used [18]. Culture supernatants of the Lactobacillus strains were obtained to evaluate acid production. The cultures were grown in MRS broth for $48 \mathrm{~h}$ at $37^{\circ} \mathrm{C}$ and then centrifuged $(8000 \times g, 15 \mathrm{~min})$. The supernatant was separated from the pellet, and the $\mathrm{pH}$ was measured with a $\mathrm{pH}$ meter.

2.7. Susceptibility of Lactobacilli to Antibiotics. The antibiotics susceptibility profiles of the Lactobacillus strains were determined by using the modified agar diffusion method of Clinical and Laboratory Standards Institute (CLSI) [22]. Lactobacilli were grown in MRS broth for $18 \mathrm{~h}$ at $37^{\circ} \mathrm{C}$ in anaerobic jar and then centrifuged $(8000 \times g, 10 \mathrm{~min})$. The cell pellets were washed twice with $0.9 \%$ saline solution (w/v) and adjusted to 0.5 MacFarland. Then, $100 \mu \mathrm{L}$ of this suspension was spread on MRS agar plates, and antibiotic disks were placed on the plates. The plates were incubated at $37^{\circ} \mathrm{C}$ for $24 \mathrm{~h}$, and then the diameter of the zone of inhibition surrounding each disk was measured and classified as sensitive (S), moderately sensitive (MS), or resistant (R), according to Charteris et al. [23]. The antibiotics tested were amoxicillin $(10 \mu \mathrm{g})$, ampicillin $(10 \mu \mathrm{g})$, cephalothin $(30 \mu \mathrm{g})$, ciprofloxacin $(5 \mu \mathrm{g})$, clindamycin $(2 \mu \mathrm{g})$, chloramphenicol $(30 \mu \mathrm{g})$, erythromycin $(10 \mu \mathrm{g})$, gentamicin $(10 \mu \mathrm{g})$, nitrofurantoin $(300 \mu \mathrm{g})$, norfloxacin $(10 \mu \mathrm{g})$, penicillin $\mathrm{G}(10 \mu \mathrm{g})$, tetracycline $(30 \mu \mathrm{g})$, and vancomycin $(30 \mu \mathrm{g})$.

2.8. Interactions between HMVII Cells and LAMP and the Effect of Lactobacillus Strains. To assess the interactions between Mycoplasma and Ureaplasma LAMP and HMVII cells, first a monolayer of HMVII cells, at a concentration of $1 \times 10^{6}$ cells/well, was grown in 24 -well plates in an incubator $(\mathrm{SANYO})$ at $37^{\circ} \mathrm{C}$ and $5 \% \mathrm{CO}_{2}$. After $24 \mathrm{~h}$, the interactions between the lactobacilli strains and the lipoproteins tested were added to the wells of the plates, according to Table 1. The concentration of LAMP used in study $(4 \mu \mathrm{g} / \mathrm{mL})$ was determined from previous tests evaluating the dose response of HMVII cells to the lipoproteins (data not shown). And the suspensions of lactobacilli were adjusted to $1 \times 10^{8} \mathrm{CFU} / \mathrm{mL}$ in RPMI supplemented with $10 \%$ FBS.

2.9. Flow Cytometry to Assess the Viability of HMVII Cells. After the HMVII cells were incubated with the Lactobacillus strains and/or lipoproteins for $24 \mathrm{~h}$, they were disrupted by trypsinization, washed twice with PBS and collected by centrifugation $(600 \mathrm{x} g, 10 \mathrm{~min})$. The cells were labelled using LIVE/DEAD ${ }^{\text {тм }}$ Viability/Cytotoxicity Kit for mammalian cells (Invitrogen/Thermo Fisher Scientific, Carlsbad, CA, USA) according to the manufacturer's instructions. Fluorescence was analyzed on a FC 500 flow cytometer (Beckman Coulter) with 20,000 events.

2.10. Scanning Electron Microscopy (SEM). Scanning electron microscopy was performed to confirm Lactobacillus adhesion to the vaginal cells (after $2 \mathrm{~h}$ ), as well as demonstrate the 
TABLE 1: Interactions between vaginal cells and Mollicutes lipoproteins in the presence and/or absence of lactobacilli isolated from cocoa fermentation.

\begin{tabular}{llr}
\hline Lipoproteins & Lactobacillus fermentum FA4 & Lactobacilli \\
\hline $\begin{array}{l}\text { Ureaplasma parvum } \\
\text { (UuLAMP) }\end{array}$ & UpLAMP + L. fermentum FA4 & UpLAMP + L. plantarum PA3 \\
$\begin{array}{l}\text { Ureaplasma urealyticum } \\
\text { (UpLAMP) }\end{array}$ & UuLAMP + L. fermentum FA4 \\
$\begin{array}{l}\text { Mycoplasma hominis } \\
\text { (MhLAMP) }\end{array}$ & MhLAMP + L. fermentum FA4 & UuLAMP + L. plantarum PA3 \\
$\begin{array}{l}\text { Mycoplasma genitalium } \\
\text { (MgLAMP) }\end{array}$ & MgLAMP + L. fermentum FA4 & MhLAMP + L.plantarum PA3 \\
\hline
\end{tabular}

physical integrity of the HMIVII cells after interaction with the lipoproteins and Lactobacillus strains (after $24 \mathrm{~h}$ ). After the incubation period, the culture supernatant was removed from each well, and the cells on the coverslips were fixed with $2.5 \%$ glutaraldehyde in $0.1 \mathrm{M}$ cacodylate buffer for at least $4 \mathrm{~h}$. Next, the samples were washed with $0.1 \mathrm{M}$ cacodylate buffer for $5 \mathrm{~min}$, twice, and then dehydrated with increasing concentrations of acetone (50-100\%) for $10 \mathrm{~min}$. After dehydration, the samples were taken to the critical point chamber and mounted on the sample holder of the "Stub" SEM with double carbon tape. Then, they were sputter coated with a thin layer of gold, about 20-30 nm thick, with a Sputter Coater SCD 050 (Baltec) for observation in a Quanta 250 Scanning Electron Microscope (FEI Company).

2.11. Statistical Analysis. All analyses were performed in triplicate. Quantitative data are expressed as the mean and standard deviation and analyzed with GraphPad Prism software (version 5.01).

For the hydrophobicity, autoaggregation, and adhesion tests, the statistical differences were determined by t-test followed by the Mann-Whitney posttest, and a $\mathrm{p}$ value less than 0.05 was considered significant. The statistical differences in the flow cytometry results were determined by ANOVA followed by Tukey's posttest, and a p value less than 0.01 was considered significant.

\section{Results and Discussion}

3.1. Evaluation of the Probiotic Properties of Lactobacilli Isolated from Cocoa Fermentation. To test whether the test Lactobacillus strains had probiotic properties, their surface properties, including autoaggregation and hydrophobicity, adherence to vaginal epithelial cells, and acid production in culture, were evaluated.

Autoaggregation percentages for L. fermentum FA4 and L. plantarum PA3 were $28.55 \%$ and $31.82 \%$, respectively (Table 2). Bacterial autoaggregation, defined as the ability of cells to form precipitates, is considered an important probiotic property, as it is directly related to adhesion to host cell surfaces, one of the mechanisms by which probiotics compete with pathogenic bacteria [24]. These values were within the expected range, since there is great variation in autoaggregation among strains of both human vaginal microbiota and nonhuman origin [25, 26]. Gómez et al. [27] found autoaggregation values ranging from 20 to $70 \%$, after only $24 \mathrm{~h}$ of incubation, among 8 strains of LAB isolated from different food sources, and the highest percentage, $67 \%$, was a Weissella viridescens strain isolated from mature cheese. Similar to our study, the two strains of L. plantarum and one strain of L. fermentum isolated from cocoa fermentation showed autoaggregation values of approximately 29\%, 33\%, and $31 \%$ after $5 \mathrm{~h}$ of incubation [18].

The hydrophobicity or microbial adhesion to hydrocarbons (MATH) can be classified as low (MATH $<33 \%$ ), medium $(33 \%<$ MATH $<66 \%)$, or high $($ MATH $>66 \%)$ [28]. The hydrophobicity of L. fermentum FA4 was considered to be average for both xylene $(57.03 \%)$ and toluene $(65.33 \%)$, while that of L. plantarum PA3 was considered high for both xylene and toluene (66.75 and 71.12\%, resp.). Some authors present hydrophobicity as microbial adhesion to solvents (MATS), classifying the bacterial surface as hydrophobic (MATS $\geq 55.00 \%)$, amphiphilic $(45.00 \% \leq$ MATS $\leq 54.99 \%)$, or hydrophilic (MATS $\leq 44.99 \%)[29,30]$. According to this classification, L. fermentum FA 4 and L. plantarum are considered to be hydrophobic. This methodology is a simple way of evaluating the hydrophobicity of potential probiotic cell lines, indicating their ability to adhere to apolar surfaces, such as epithelial cell membranes. Their hydrophobicity justifies the application of these bacteria in probiotic formulations [30]. Similar results were obtained in other studies of isolates from nonhuman sources. For example, Cui et al. [31] determined hydrophobicities of $44 \%$ to $78 \%$ in lactobacilli isolated from artisanal cheese. In the present study, lactobacilli isolated from a cocoa fermentation showed higher hydrophobicities than several isolates of intestinal origin. In a study conduced by Yadav et al. [32], the highest hydrophobicity among $L$. plantarum isolates from human feces was $39.49 \%$.

The percentage of cells that adhered to the vaginal cells was $31.66 \%$ for L. fermentum FA 4 and $41.65 \%$ for L. plantarum PA3 after $2 \mathrm{~h}$ of incubation. Adhesion was confirmed by SEM, in which it was possible to observe lactobacilli adhered to the surface of the HMVII cells (Figure 1). Adhesion is considered to be one of the major properties of a probiotic strain, because it is thought that the longer the strain remains adhered to the surface of the host cells, the more benefits it can confer. Probiotics are able to induce the expression of adhesins, such as mucin, fibronectin, collagen, laminin, and fibrinogen, which 


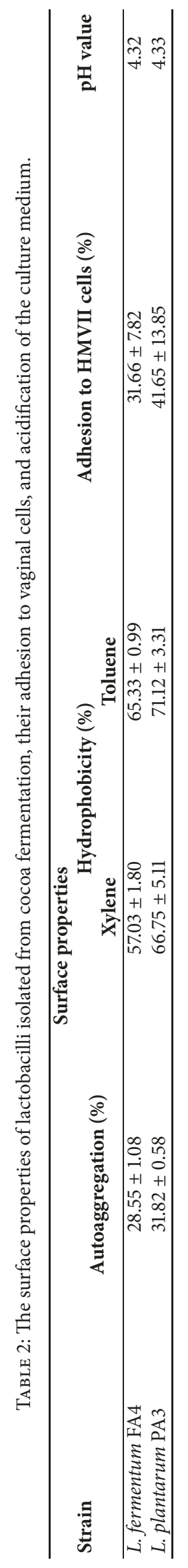




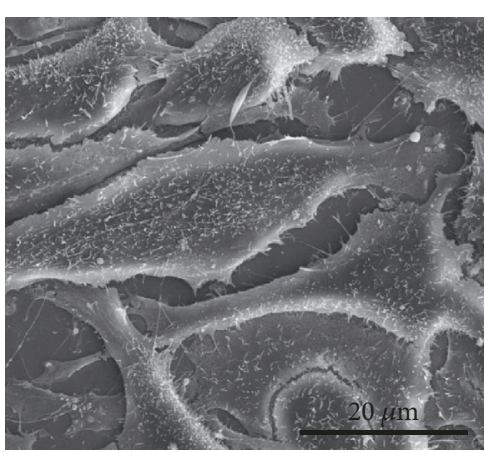

(a)

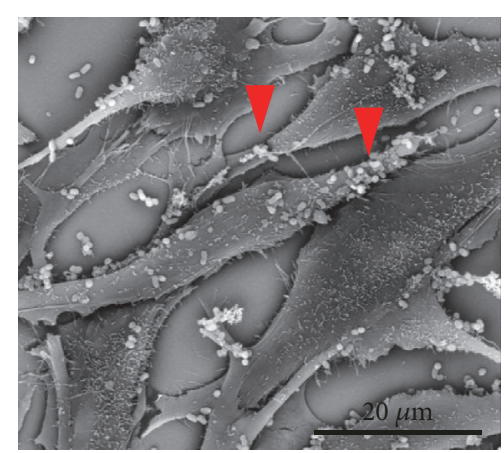

(b)

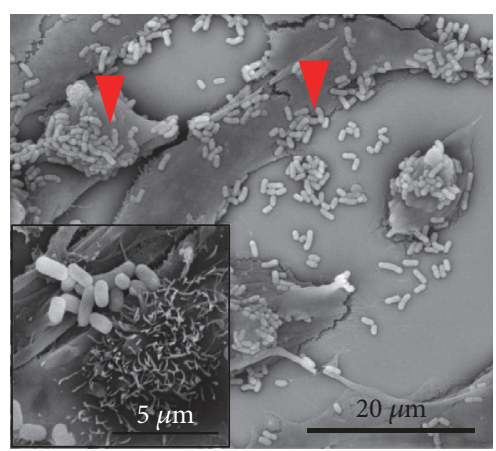

(c)

FIGURE 1: Adhesion of lactobacilli isolated from cocoa fermentation to vaginal epithelial cells after $2 \mathbf{h}$ of incubation. (a) Untreated HMVII cells (×5000); (b) HMVII cells incubated with L. fermentum FA4 (×5000); (c) HMVII cells incubated with L. plantarum PA3 ( $\times 5,000$, details at $\times 20,000)$. Red arrows indicate the lactobacilli attached to the cell surface.

mediate adhesion [32,33]. Strains of Lactobacillus paracasei subsp. paracasei produce an aggregation promoting factor (AggLb) that contributes to its high aggregation capacity, as well as a strong, specific interaction with host cell collagen, indicating that there is a direct relationship between cell aggregation, hydrophobicity, and collagen binding, as was observed in the Lactobacillus strains used in this study [34].

By evaluating the $\mathrm{pH}$ of the culture supernatants, we observed that the two Lactobacillus strains were able to reduce the $\mathrm{pH}$ of the culture medium from an initial $\mathrm{pH}=6.6$ to similar $\mathrm{pH}$ values of 4.32 for L. fermentum FA4 and 4.33 for L. plantarum PA3 (Table 2). This reduction in $\mathrm{pH}$ by lactobacilli is mediated by the production of acids, mainly lactic and acetic acids, and is one of the mechanisms by which the growth of pathogenic bacteria is inhibited $[35,36]$. In Gram-negative bacteria, lactic acid acts as a permeator of the bacterial outer membrane, releasing lipopolysaccharides (LPS), and increasing their susceptibility to other antibiotics produced by the host [37]. According to the ability to ferment sugars lactobacilli can be classified into homofermentative species (e.g., L. plantarum), which convert sugars into lactic acid, and heterofermentative species (e.g., L. fermentum), which produce lactic and acetic acids, ethanol, and $\mathrm{CO}_{2}$ [38]. Thus, contrary to what was observed in the present study, other authors have reported variations in the $\mathrm{pH}$ values of the culture medium for different species, indicating differences in acid production and secretion profiles; generally, $L$. plantarum strains tend to produce more acid than $L$. fermentum strains [18]. Among vaginal Lactobacillus isolates with inhibitory potential against $G$. vaginalis, an L. fermentum strain reduced the $\mathrm{pH}$ of the culture supernatant to $\mathrm{pH} 4.16$ after $48 \mathrm{~h}$ of incubation [39], whereas 2 strains of L. plantarum isolated from organic fertilizer, in the same conditions for $24 \mathrm{~h}$, reduced the $\mathrm{pH}$ to 3.83 and 3.88 [40]. Two strains of L. plantarum isolated from a cocoa fermentation reduced the $\mathrm{pH}$ to 3.81 and 3.77, whereas an L. fermentum isolate reduced the $\mathrm{pH}$ to 4.78 [18].

The tested L. fermentum FA4 and L. plantarum PA3 strains did not show any significant differences in the four parameters evaluated, indicating that they have similar probiotic potential.
3.2. Susceptibility of Lactobacilli to Antibiotics. In the antibiotics sensitivity profile testing, the two Lactobacillus strains were sensitive or moderately sensitive to most of the antibiotics tested. They were only resistant to vancomycin, aminoglycosides, and quinolones (Table 3). Although lactobacilli are "generally recognized as safe", safety tests, such as the determination of antibiotics sensitivity profiles, should always be performed to avoid the transfer of resistance genes, since these profiles vary among species [41]. Similar sensitivity profiles have been described in other studies, corroborating the findings of the present study. Santos et al. [42] found that $L$. fermentum and $L$. plantarum isolates from cocoa fermentation were resistant to vancomycin and quinolone class antibiotics. Similarly, 12 lactobacilli strains isolated from cottage cheese, typical of northeastern China, were resistant to streptomycin, gentamicin, vancomycin, and ciprofloxacin [31]. Strains of human origin also have similar sensitivity profiles. Bouridani et al. [25] showed that all tested vaginal Lactobacillus isolates were resistant to ofloxacin, gentamicin, and ciprofloxacin, and almost all strains were sensitive to trimethoprim-sulfamethoxazole, ampicillin, erythromycin, cefotaxime, chloramphenicol, tetracycline, and nitrofurantoin. Bacteria in the genus Lactobacillus, like other Grampositive bacteria, are intrinsically resistant to glycopeptides such as vancomycin. However, the gene responsible for this resistance is chromosomal, and it is not inducible or transferable to other bacteria $[43,44]$. Thus, the strains under study could be used in therapeutic applications, as they would not pose a risk to the health of humans or other animals.

3.3. Interaction of HMVII Cells with Lipoproteins and the Effects of Treatment with Lactobacilli. Initially, we evaluated whether lactobacilli isolated from cocoa fermentation reduced the viability of cells of vaginal lineage. After $24 \mathrm{~h}$ of incubation with $L$. fermentum FA4 and L. plantarum PA3, the HMVII cells showed cell death rates of only $0.72 \%$ and $0.36 \%$, respectively, and these rates were not significantly different from each other or from that of the control (1.99\%; Figure 2).

This minimal reduction in HMVII cell viability after incubation with these Lactobacillus strains demonstrates that 


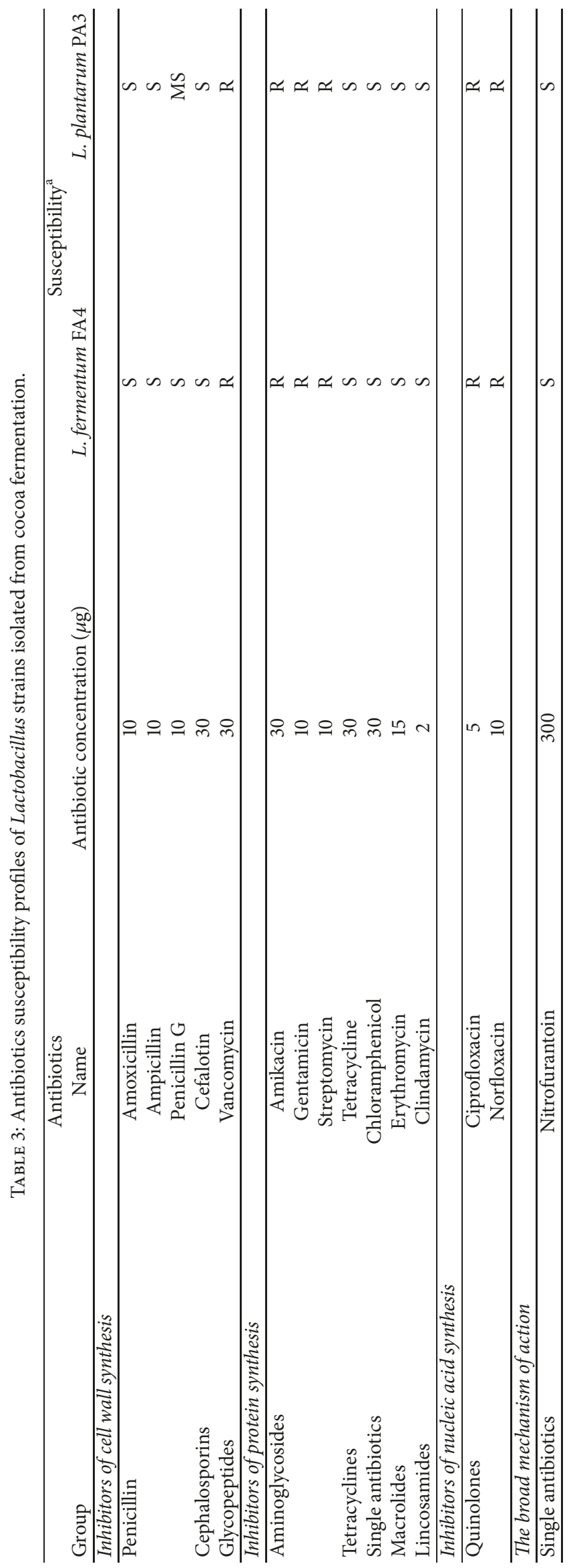




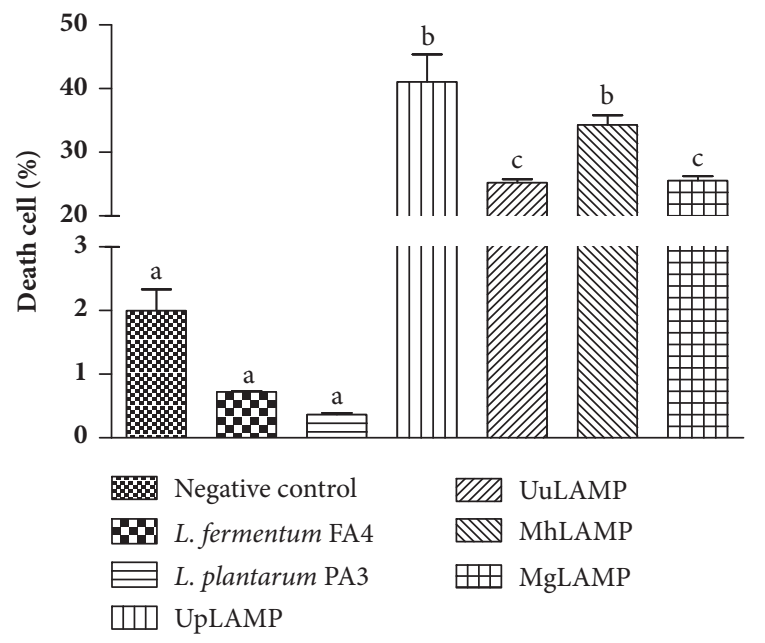

FIGURE 2: Death of HMVII cells after $24 \mathrm{~h}$ of incubation with $\mathrm{Lac}$ tobacillus strains or membrane-associated lipoproteins (LAMP) from $U$. parvum (UpLAMP), U. urealyticum (UuLAMP), $M$. hominis (MhLAMP), or M. genitalium (MgLAMP). Different letters indicate significant differences $(\mathrm{p}<0.01)$.

both can exist in the human vaginal environment without any toxicity. In addition, they reinforce the probiotic potential of these strains in protecting against pathogens that cause BV. Similarly, Abramov et al. [45] showed that Lactobacillus crispatus 2029 did not induce apoptosis in vaginal epithelium cells (VK2/E6E7) and has no cytotoxic effects on them. Strains of $L$. fermentum and L. plantarum inhibited apoptosis in HeLa epithelial cells and showed antagonistic activity against Candida albicans and G. vaginalis [46]. In another study, the viability of cells isolated from epidermoid carcinoma of the cervix (CaSki) and HeLa cells was maintained after incubation with different concentrations of Lactobacillus casei extract [47]. In contrast, cell death of HMVII cells increased significantly after incubation with the membrane-associated lipoproteins (LAMP) of U. parvum, $U$. urealyticum, $M$. hominis, and $M$. genitalium; LAMP extracted from U. parvum and M. hominis induced $41 \%$ and $34 \%$ cell death, respectively, the highest values among the 4 species (Figure 2).

Mollicutes causing genital infections need to adhere and subsequently invade the cells of the genitourinary tract to obtain nutrients from the host cells $[1,2,47]$. During adhesion, human cells first interact with the plasma membrane of these microorganisms, specifically with their lipoproteins. Recently, cytoadhesion and invasion present on the membrane of M. hominis were shown to interact with HeLa cells [48]. Hopfe et al. [49] showed that, after $4 \mathrm{~h}$ of infection of HeLa cells with M. hominis, genes related to the cell cycle, growth, and cell death are highly regulated, and lipoproteins are generally responsible for inducing inflammation, apoptosis, and cell death $[5,50]$.

The present study is the first to use the HMVII vaginal cell line as a model for interaction with the lipoproteins of Mollicutes, mimicking the infection that occurs in vivo. However, the levels of cell death induced by lipoproteins extracted

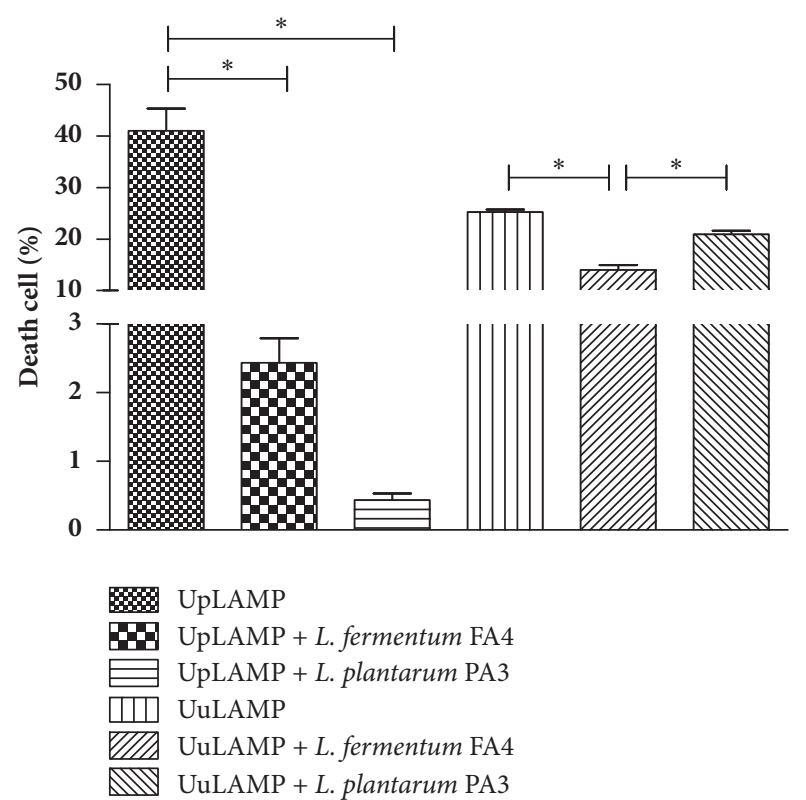

FIGURE 3: Death of HMVII cells after $24 \mathrm{~h}$ of incubation with LAMP from U. parvum (UpLAMP) or U. urealyticum (UuLAMP) with and without L. plantarum PA3 or L. fermentum FA4. $* p<0.01$ compared to cells with LAMP alone.

from mycoplasmas and ureaplasmas may vary according to both species and the human cell line used in the experiment. Similarly, to the present study, $2 \mu \mathrm{g} / \mathrm{mL}$ Mycoplasma penetrans lipoproteins induced apoptosis in RAW264.7 murine macrophages [51]. LAMP from Mycoplasma salivarium and Mycoplasma fermentans caused both apoptosis and necrosis in myeloid (HL-60 and THP-1) and lymphoid (MOLT-4 and Raji cells) leukemia cells at concentrations of 20 and $7 \mu \mathrm{g} / \mathrm{mL}$, respectively [52]. However, Bai et al. (2007) [4] showed that Mycoplasma hyopneumoniae LAMP induced apoptosis in the $3 \mathrm{D} 4 / 21$ porcine alveolar macrophage (PAM) cell line at concentrations of $0.4 \mathrm{mg} / \mathrm{mL}$ or higher, which is higher than the concentration used in the present study.

In this study, we also demonstrated that incubation of HMVII cells with lactobacilli isolated from cocoa fermentation significantly reduced cell death caused by the interaction with Ureaplasma species LAMP from $41.03 \%$ in UpLAMP to 2.43\% (UpLAMP + L. fermentum FA 4) and 0.43\% (UpLAMP + L. plantarum PA3) and from $25.24 \%$ (UuLAMP) to $13.97 \%$ (UuLAMP + L. fermentum FA4) (Figure 3). As described for the genus Ureaplasma, the treatment of HMVII with lactobacilli also managed to significantly decrease the rate of cell death caused by the interaction with LAMP of the genus Mycoplasma. The cell death reduced from 34.29\% (MhLAMP) to $14.06 \%$ (MhLAMP + L. fermentum FA4) and $14.61 \%($ MhLAMP + L. plantarum PA3) and 25.53 (MgLAMP) to $8.91 \%$ (MgLAMP + L. fermentum FA4) and 11\% (MgLAMP + L. plantarum PA3) (Figure 4).

The findings of flow cytometry were confirmed by microscopy (Figures 5-8). The images showed the vaginal cells after interaction with lipoproteins extracted from $U$. parvum, U. urealyticum, M. hominis, and M. genitalium 


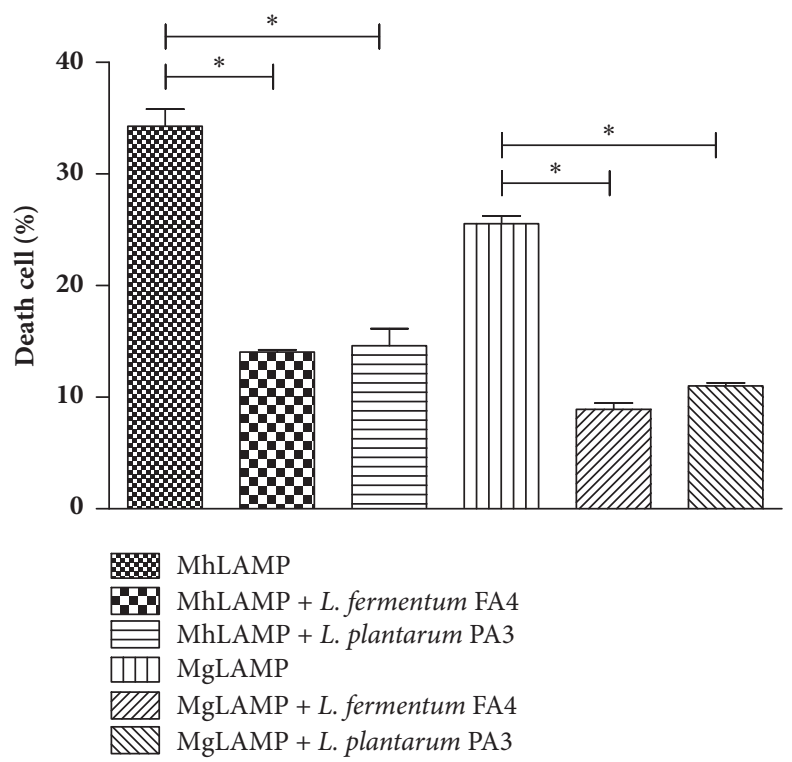

FIgURE 4: Death of HMVII cells after $24 \mathrm{~h}$ of incubation with LAMP from M. hominis (MhLAMP) or M. genitalium (MgLAMP) with and without L. plantarum PA3 or L. fermentum FA4. $* p<0.01$ compared to cells with LAMP alone.

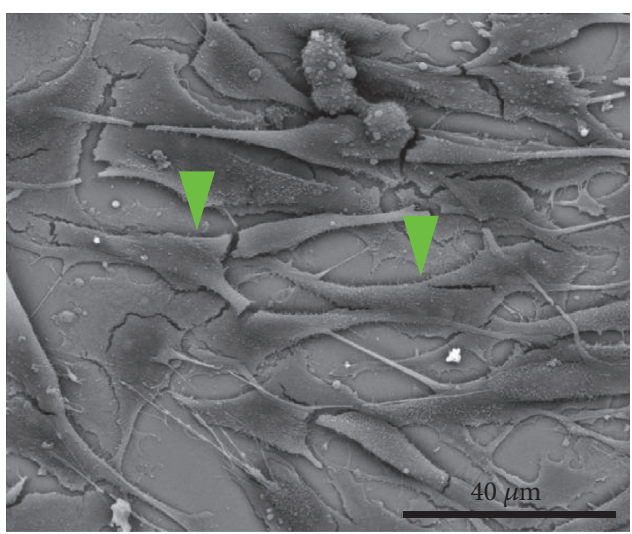

(a)

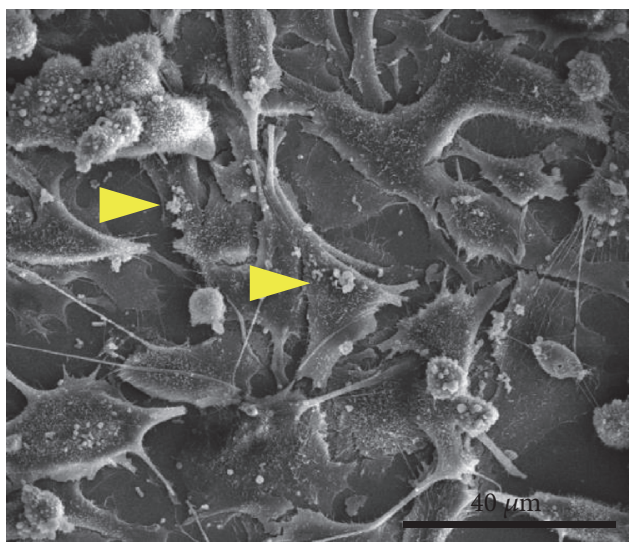

(c)

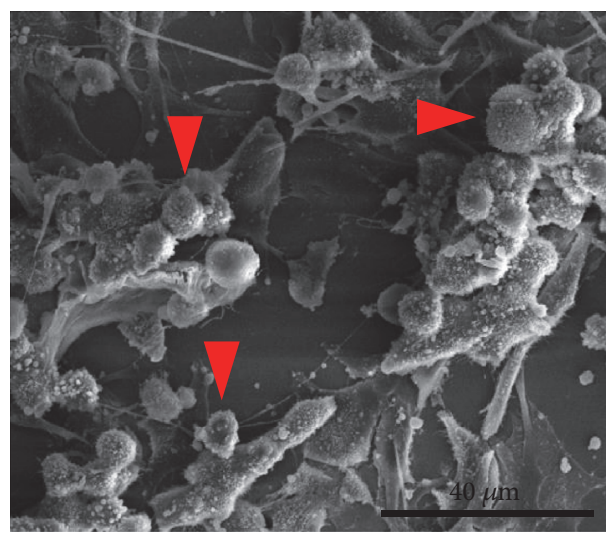

(b)

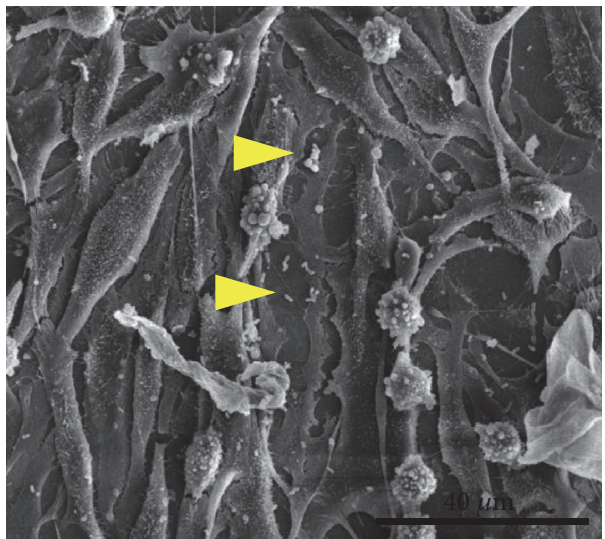

(d)

FIGURE 5: Interaction of HMVII cells with $4 \mu \mathrm{g} / \mathrm{mL}$ of $U$. parvum LAMP with and without $L$. fermentum FA4 or L. plantarum PA3. (a) Control (HMVII cells alone). (b) HMVII with UpLAMP. (c) HMVII with UpLAMP and L. fermentum FA4. (d) HMVII with UpLAMP and L. plantarum PA3. Green arrows indicate intact HMVII cells, red arrows indicate HMVII cells with altered morphology, and yellow arrows indicate lactobacilli adhered to whole cells (scanning electron microscopy, $\times 2500$ ). 


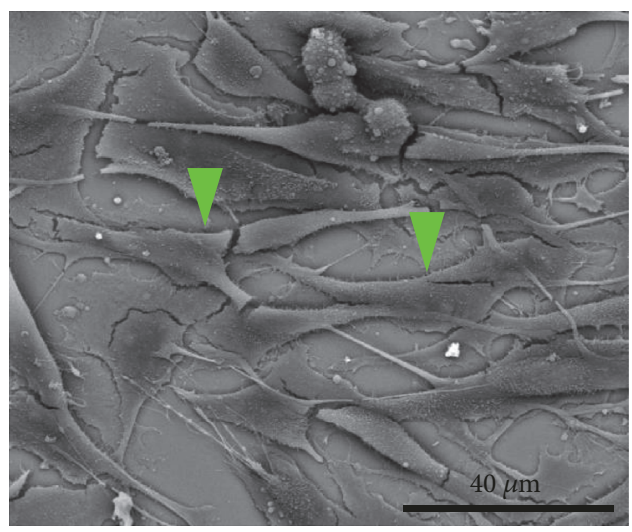

(a)

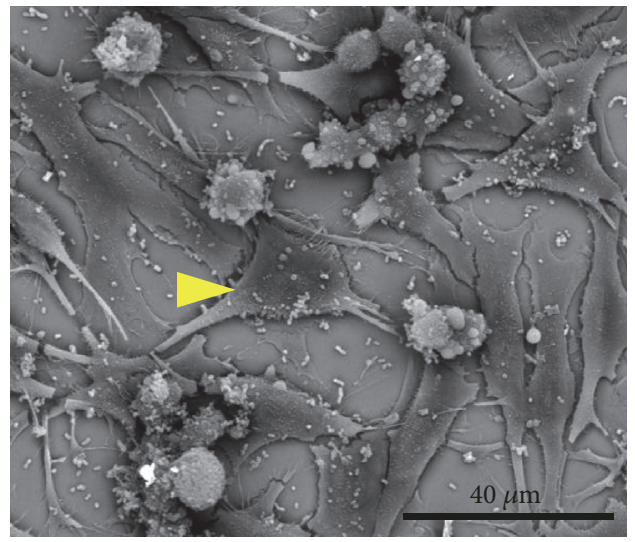

(c)

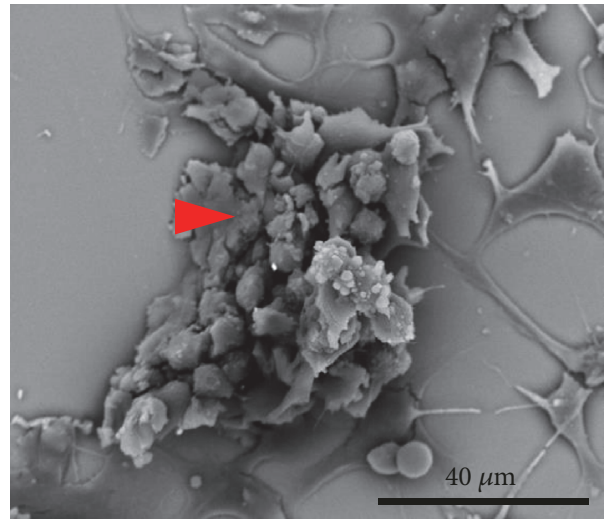

(b)

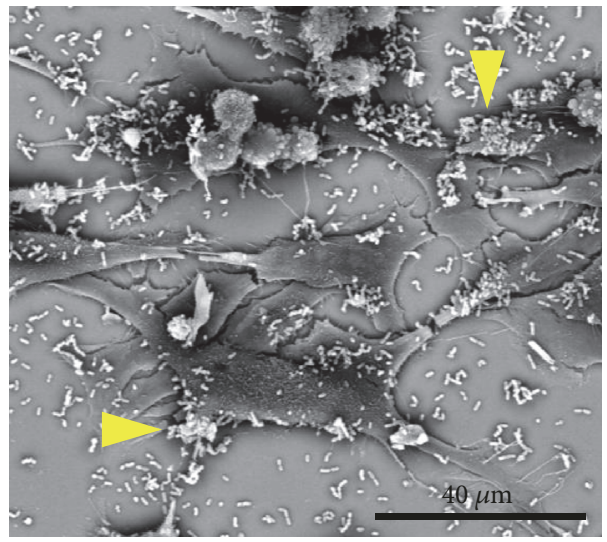

(d)

FIgURE 6: Interaction of HMVII cells with U. urealyticum LAMP with and without L. fermentum FA4 or L. plantarum PA3. (a) Control (HMVII cells alone). (b) HMVII with UuLAMP. (c) HMVII with UuLAMP and L. fermentum FA4. (d) HMVII with UuLAMP and $L$. plantarum PA3. Green arrows indicate intact HMVII cells, red arrows indicate HMVII cells with altered morphology, and yellow arrows indicate lactobacilli adhered to whole cells (scanning electron microscopy, $\times 2500$ ).

(resp.) and treatment with the two strains of lactobacilli. Cells incubated only with lipoproteins at a concentration of $4 \mu \mathrm{g} /$ $\mathrm{mL}$ (Figures 5(b)-8(b)) presented a large number of cells with altered morphology, when compared to the control (Figures $5(\mathrm{a})-8(\mathrm{a}))$.

In contrast, in treatments with L. fermentum FA4 (Figures 5(c)-8(c)) and L. plantarum PA3 (Figures 5(d)-8(d)), bacteria adhered to HMVII cells were able to reduce cell death. This property was evidenced by normal morphological characteristics of the cells compared to the negative control.

Several studies have shown that lactobacilli isolated from the vaginal environment have activity against potentially pathogenic bacteria. Strains of $L$. crispatus and L. vaginalis inhibited the growth of several bacterial species causing vaginal and urinary tract infections, including Enterococcus faecalis, E. coli, S. aureus, Enterococcus faecium, G. vaginalis, and Proteus mirabilis [53]. In addition to promoting a protective vaginal environment, strains of L. crispatus showed antagonistic activity against several species of the genus Candida [45]. Strains of Lactobacillus rhamnosus and Lactobacillus reuteri increased the viability of human epidermal keratinocytes from $8.8 \%$ after infection with $S$. aureus to $42.7 \%$ and $53.1 \%$, respectively [54]. However, very few studies have examined the interaction between lactobacilli and Mollicutes. Danielle et al. [55] demonstrated that bacteriocins produced by L. fermentum and L. rhamnosus showed antibacterial activity against vaginal isolates of $U$. urealyticum and M. hominis. This is the first study to investigate the interaction between Lactobacillus strains isolated from cocoa fermentation and the Mollicutes class of bacteria. The antagonist effects of probiotic microorganisms against pathogenic bacteria include competitive adhesion to the mucosa and epithelium; strengthening of the epithelial barrier; secretion of antibiotics substances, such as bacteriocins and organic acids; and modulation of the immune system [36].

One possible protective mechanism of the strains in this study against Mycoplasma and Ureaplasma lipoproteins is competitive adhesion to host epithelial cells. The excellent adhesion capacity and hydrophobicity of the strains in this study suggest antagonistic effects on the adhesion of LAMP to the plasma membrane of the vaginal epithelium. In addition, this high hydrophobicity, coupled with the self-aggregation 


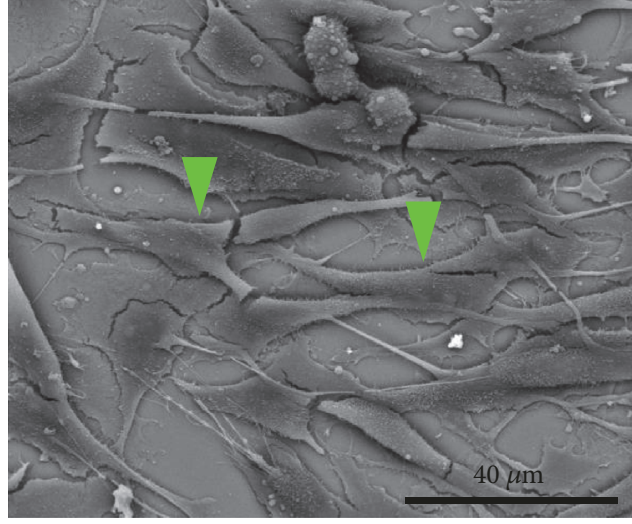

(a)

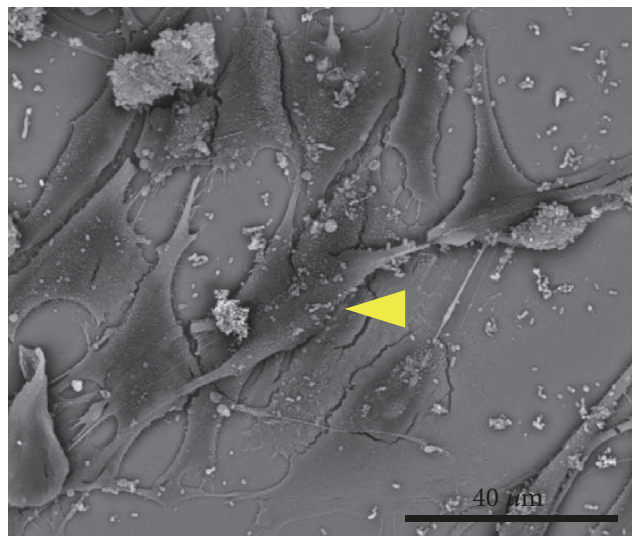

(c)

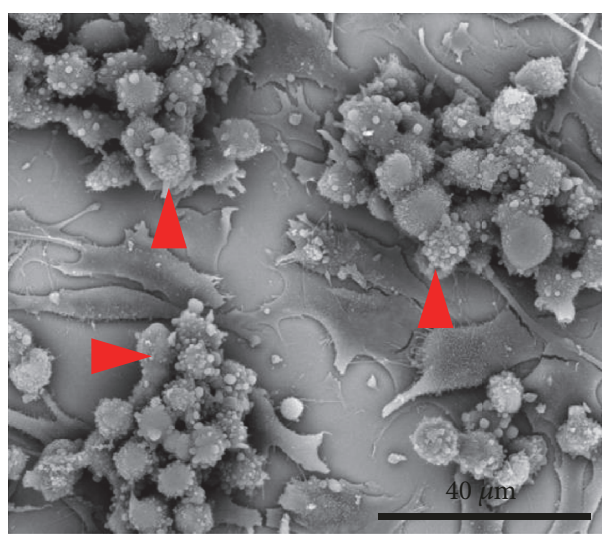

(b)

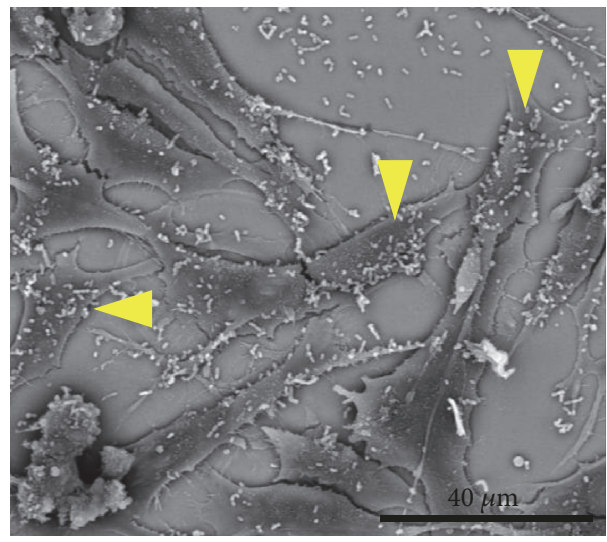

(d)

FIGURE 7: Interaction of HMVII cells with $4 \mu \mathrm{g} / \mathrm{mL}$ of $M$. hominis LAMP with and without L. fermentum FA4 or L. plantarum PA3. (a) Control (HMVII cells alone). (b) HMVII with MhLAMP. (c) HMVII with MhLAMP and L. fermentum FA4. (d) HMVII with MhLAMP and L. plantarum PA3. Green arrows indicate intact HMVII cells, red arrows indicate HMVII cells with altered morphology, and yellow arrows indicate lactobacilli adhered to whole cells (scanning electron microscopy, $\times 2500$ ).

ability, of the tested lactobacilli may cause the LAMP to bind to the cell wall of these microorganisms rather than to the epithelial cell membrane [35]. Finally, the cell interaction experiment results indicate that these L. fermentum and $L$. plantarum strains isolated from cocoa fermentation have potential for use as vaginal cell protectors against the LAMP of several important pathogens of the genitourinary tract, including $U$. parvum, U. urealyticum, M. hominis, and $M$. genitalium. However, more studies are needed to clarify their protective mechanism(s) of action.

\section{Conclusions}

In the present study, lactobacilli isolated from cocoa fermentation inhibited cell death of a vaginal cell line (HMVII) induced by Mollicutes lipoproteins (Mycoplasma and Ureaplasma strains) that cause genital infections. The tested Lactobacillus strains have the fundamental and desirable probiotic properties required to maintain a healthy vaginal environment, including high hydrophobicity and autoaggregation, as well as adherence to epithelial cells and acid production. These characteristics are considered promising for the development of further prophylactic agents.

\section{Data Availability}

The data used to support the findings of this study are included within the article.

\section{Conflicts of Interest}

The authors declare that there are no conflicts of interest regarding the publication of this paper.

\section{Acknowledgments}

This research is supported by funding from Fundação de Amparo à Pesquisa do Estado da Bahia (FAPESB) (Projects nos. 4450/2012 and 4825/2015). 


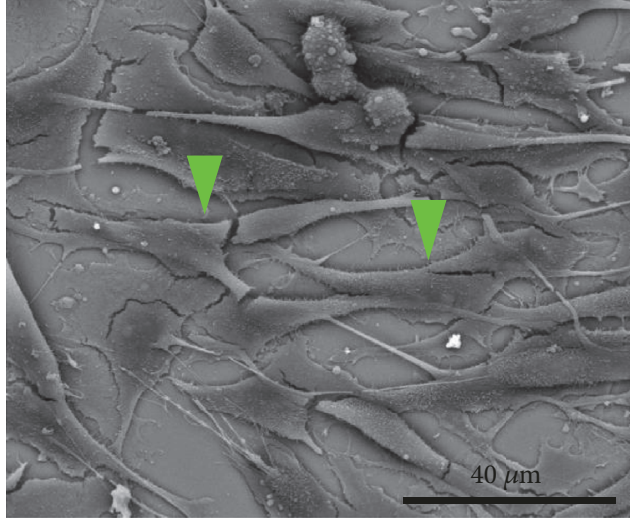

(a)

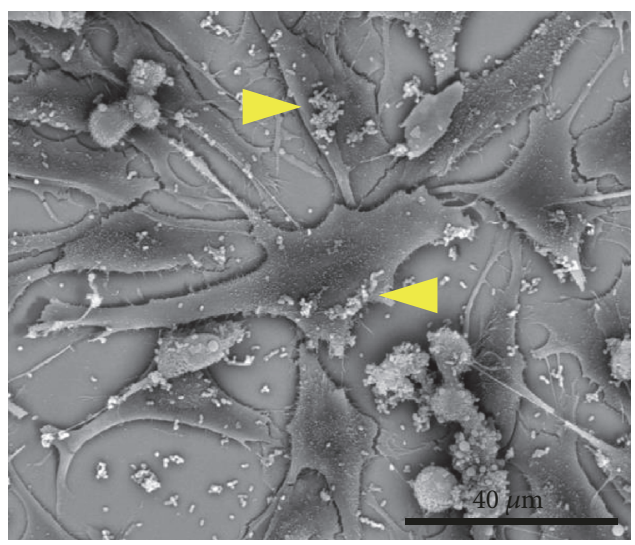

(c)

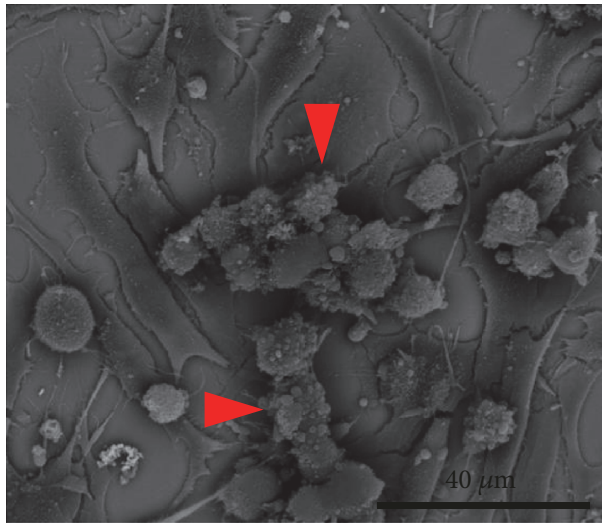

(b)

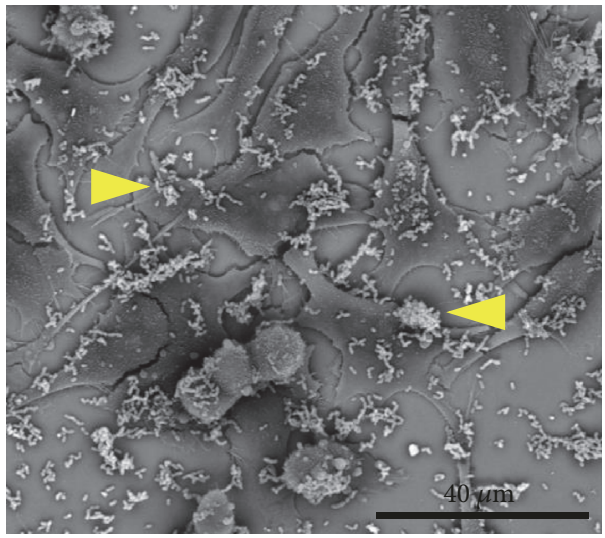

(d)

FIGURE 8: Interaction of HMVII cells with $4 \mu \mathrm{g} / \mathrm{mL}$ M. genitalium lipoproteins with and without L. fermentum FA4 or L. plantarum PA3. (a) Control (HMVII cell alone). (b) HMVII with MgLAMP. (c) HMVII with MgLAMP and L. fermentum FA4. (d) HMVII with MgLAMP and L. plantarum PA3. Green arrows indicate intact HMVII cells, red arrows indicate HMVII cells with altered morphology, and yellow arrows indicate lactobacilli adhered to whole cells (scanning electron microscopy $\times 2500$ ).

\section{References}

[1] S. Rottem and Y. Naot, "Subversion and exploitation of host cells by mycoplasmas," Trends in Microbiology, vol. 6, no. 11, pp. 436440, 1998.

[2] S. Rottem, "Interaction of mycoplasmas with host cells," Physiological Reviews, vol. 83, no. 2, pp. 417-432, 2003.

[3] G. Rawadi, "Mycoplasma fermentans interaction with monocytes/macrophages: Molecular basis," Microbes and Infection, vol. 2, no. 8, pp. 955-964, 2000.

[4] F. Bai, B. Ni, M. Liu et al., "Mycoplasma hyopneumoniaederived lipid-associated membrane proteins induce apoptosis in porcine alveolar macrophage via increasing nitric oxide production, oxidative stress, and caspase-3 activation," Veterinary Immunology and Immunopathology, vol. 155, no. 3, pp. 155-161, 2013.

[5] F. Bai, B. Ni, M. Liu, Z. Feng, Q. Xiong, and G. Shao, "Mycoplasma hyopneumoniae-derived lipid-associated membrane proteins induce inflammation and apoptosis in porcine peripheral blood mononuclear cells in vitro," Veterinary Microbiology, vol. 175, no. 1, pp. 58-67, 2015.

[6] M. J. Redelinghuys, M. M. Ehlers, A. W. Dreyer, H. Lombaard, S. A. S. Olorunju, and M. M. Kock, "A cross-sectional study on the relationship of age, gestational age and HIV infection to bacterial vaginosis and genital mycoplasma infection," $B M J$ Open, vol. 5, no. 10, Article ID e008530, 2015.

[7] J. E. Balkus, L. E. Manhart, J. S. Jensen et al., "Mycoplasma genitalium infection in Kenyan and US women," Sexually Transmitted Diseases, vol. 45, pp. 514-521, 2018.

[8] C. A. Spiegel, "Bacterial vaginosis," Clinical Microbiology Reviews, vol. 4, no. 4, pp. 485-502, 1991.

[9] N. Van Oostrum, P. De Sutter, J. Meys, and H. Verstraelen, "Risks associated with bacterial vaginosis in infertility patients: a systematic review and meta-analysis," Human Reproduction, vol. 28, no. 7, pp. 1809-1815, 2013.

[10] I. Sirota, S. M. Zarek, and J. H. Segars, "Potential influence of the microbiome on infertility and assisted reproductive technology," Seminars in Reproductive Medicine, vol. 32, no. 1, pp. 35-42, 2014.

[11] M. I. Petrova, E. Lievens, S. Malik, N. Imholz, and S. Lebeer, "Lactobacillus species as biomarkers and agents that can promote various aspects of vaginal health," Frontiers in Physiology, vol. 6, 2015.

[12] A. C. Ouwehand, S. Salminen, and E. Isolauri, "Probiotics: an overview of beneficial effects," Antonie van LeeuwenhoekJournal of Microbiology, vol. 82, no. 1-4, pp. 279-289, 2002. 
[13] FAO/WHO, "Health and nutritional properties of probiotics in food including powder milk with live lactic acid bacteria," http://www.fao.org/home/en/, 2001.

[14] G. V. D. M. Pereira, M. G. D. C. P. Miguel, C. L. Ramos, and R. F. Schwan, "Microbiological and physicochemical characterization of small-scale cocoa fermentations and screening of yeast and bacterial strains to develop a defined starter culture," Applied and Environmental Microbiology, vol. 78, no. 15, pp. 5395-5405, 2012.

[15] C. L. Ramos, L. Thorsen, R. F. Schwan, and L. Jespersen, "Strain-specific probiotics properties of Lactobacillus fermentum, Lactobacillus plantarum and Lactobacillus brevis isolates from Brazilian food products," Food Microbiology, vol. 36, no. 1, pp. 22-29, 2013.

[16] T. F. Dos Santos, T. A. Melo, D. S. Santos, R. P. Rezende, J. C. T. Dias, and C. C. Romano, "Efficacy of oral administration of lactic acid bacteria isolated from cocoa in a fermented milk preparation: Reduction of colitis in an experimental rat model," Genetics and Molecular Research, vol. 15, no. 3, 2016.

[17] T. A. Melo, T. F. Dos Santos, M. E. De Almeida et al., "Inhibition of Staphylococcus aureus biofilm by Lactobacillus isolated from fine cocoa," BMC Microbiology, vol. 16, no. 1, pp. 1-9, 2016.

[18] W. F. B. Pessoa, A. C. C. Melgaço, M. E. De Almeida, L. P. Ramos, R. P. Rezende, and C. C. Romano, "In vitro activity of lactobacilli with probiotic potential isolated from cocoa fermentation against gardnerella vaginalis," BioMed Research International, vol. 2017, 10 pages, 2017.

[19] R. Wang et al., "Mycoplasma genitalium infection and host antibody immune response in patients infected by HIV pacients attending STD clinics and in healthy blood donors," Lancet, vol. 340, pp. 312-1316, 1992.

[20] B. Kos, J. Šušković, S. Vuković, M. Sǐmpraga, J. Frece, and S. Matošić, "Adhesion and aggregation ability of probiotic strain Lactobacillus acidophilus M92," Journal of Applied Microbiology, vol. 94, no. 6, pp. 981-987, 2003.

[21] C. Rodríguez, J. V. Cofré, M. Sánchez, P. Fernández, G. Boggiano, and E. Castro, "Lactobacilli isolated from vaginal vault of dairy and meat cows during progesteronic stage of estrous cycle," Anaerobe, vol. 17, no. 1, pp. 15-18, 2011.

[22] CLSI, "Performance standards for antibiotics susceptibility testing; twenty-fifth informational supplement," CLSI document M100-S25, Clinical Laboratory Standards Institute, Wayne, PA, USA, 2015.

[23] W. P. Charteris, P. M. Kelly, L. Morelli, and J. K. Collins, "Antibiotic susceptibility of potentially probiotic Lactobacillus species," Journal of Food Protection, vol. 61, no. 12, pp. 1636-1643, 1998.

[24] B. Del Re, B. Sgorbati, M. Miglioli, and D. Palenzona, "Adhesion, autoaggregation and hydrophobicity of 13 strains of Bifidobacterium longum," Letters in Applied Microbiology, vol. 31, no. 6, pp. 438-442, 2000.

[25] H. Bouridane, M. Sifour, T. Idoui, L. Annick, and P. Thonard, "Technological and probiotic traits of the lactobacilli isolated from vaginal tract of the healthy women for probiotic use," Iranian Journal of Biotechnology, vol. 14, no. 3, pp. 132-141, 2016.

[26] L. Ouarabi, Y. A. Chait, H. A. Seddik, D. Drider, and F. Bendali, "Newly isolated lactobacilli strains from algerian human vaginal microbiota: lactobacillus fermentum strains relevant probiotic's candidates," Probiotics and Antimicrobial Proteins, vol. 1, pp. 112, 2017.

[27] N. C. Gómez, J. M. P. Ramiro, B. X. V. Quecan, and B. D. G. de Melo Franco, "Use of potential probiotic lactic acid bacteria (LAB) biofilms for the control of Listeria monocytogenes, Salmonella Typhimurium, and Escherichia coli O157: H7 biofilms formation," Frontiers in Microbiology, vol. 7, Article ID 863, 2016.

[28] D. S. Bouchard, B. Seridan, T. Saraoui et al., "Lactic acid bacteria isolated from bovine mammary microbiota: Potential allies against bovine mastitis," PLoS ONE, vol. 10, no. 12, Article ID e0144831, 2015.

[29] C. Pelletier, C. Bouley, C. Cayuela, S. Bouttier, P. Bourlioux, and M.-N. Bellon-Fontaine, "Cell surface characteristics of Lactobacillus casei subsp. casei, Lactobacillus paracasei subsp. paracasei, and Lactobacillus rhamnosus strains," Applied and Environmental Microbiology, vol. 63, no. 5, pp. 1725-1731, 1997.

[30] S. Sandes, L. Alvim, B. Silva et al., "Selection of new lactic acid bacteria strains bearing probiotic features from mucosal microbiota of healthy calves: Looking for immunobiotics through in vitro and in vivo approaches for immunoprophylaxis applications," Microbiological Research, vol. 200, pp. 1-13, 2017.

[31] X. Cui, Y. Shi, S. Gu, X. Yan, H. Chen, and J. Ge, "Antibacterial and antibiofilm activity of lactic acid bacteria isolated from traditional artisanal milk cheese from Northeast China against enteropathogenic bacteria," Probiotics and Antimicrobial Proteins, pp. 1-10, 2017.

[32] A. K. Yadav, A. Tyagi, J. K. Kaushik, A. C. Saklani, S. Grover, and V. K. Batish, "Role of surface layer collagen binding protein from indigenous Lactobacillus plantarum 91 in adhesion and its anti-adhesion potential against gut pathogen," Microbiological Research, vol. 168, no. 10, pp. 639-645, 2013.

[33] N. Buntin, W. M. de Vos, and T. Hongpattarakere, "Variation of mucin adhesion, cell surface characteristics, and molecular mechanisms among Lactobacillus plantarum isolated from different habitats," Applied Microbiology and Biotechnology, vol. 101, no. 20, pp. 7663-7674, 2017.

[34] M. Miljkovic, I. Strahinic, M. Tolinacki et al., "AggLb is the largest cell-aggregation factor from Lactobacillus paracasei subsp. paracasei bgnj1-64, functions in collagen adhesion, and pathogen exclusion in vitro," PLoS ONE, vol. 10, no. 5, Article ID e0126387, 2015.

[35] A. L. Servin, "Antagonistic activities of lactobacilli and bifidobacteria against microbial pathogens," FEMS Microbiology Reviews, vol. 28, no. 4, pp. 405-440, 2004.

[36] M. Bermudez-Brito et al., "Probiotc mechanisms of action," Annual of Nutrition and Metabolism, vol. 61, pp. 160-174, 2012.

[37] H.-L. Alakomi, E. Skyttä, M. Saarela, T. Mattila-Sandholm, K. Latva-Kala, and I. M. Helander, "Lactic acid permeabilizes gram-negative bacteria by disrupting the outer membrane," Applied and Environmental Microbiology, vol. 66, no. 5, pp. 2001-2005, 2000.

[38] T. O. Basso, F. S. Gomes, M. L. Lopes, H. V. De Amorim, G. Eggleston, and L. C. Basso, "Homo- and heterofermentative lactobacilli differently affect sugarcane-based fuel ethanol fermentation," Antonie van Leeuwenhoek-Journal of Microbiology, vol. 105, no. 1, pp. 169-177, 2014.

[39] N. W. Mclean and J. A. Mcgroarty, "Growth inhibition of metronidazole-susceptible and metronidazole-resistant strains of Gardnerella vaginalis by lactobacilli in vitro," Applied and Environmental Microbiology, vol. 62, no. 3, pp. 1089-1092, 1996.

[40] L. B. Poppi, J. D. Rivaldi, T. S. Coutinho, C. S. Astolfi-Ferreira, A. J. P. Ferreira, and I. M. Mancilha, "Effect of Lactobacillus sp. isolates supernatant on Escherichia coli O157: H7 enhances the role of organic acids production as a factor for pathogen 
control," Pesquisa Veterinária Brasileira, vol. 35, no. 4, pp. 353359, 2015.

[41] Y. Shao, W. Zhang, H. Guo, L. Pan, H. Zhang, and T. Sun, "Comparative studies on antibiotic resistance in Lactobacillus casei and Lactobacillus plantarum," Food Control, vol. 50, pp. 250-258, 2015.

[42] T. T. Santos, R. M. S. Ornellas, and L. B. Arcucio, "Characterization of lactobacilli strains derived from cocoa fermentation in the south of Bahia for the development of probiotic cultures," LWT-Food Science and Technology, vol. 73, pp. 259-266, 2016.

[43] R. R. S. Nelson, "Intrinsically vancomycin-resistant Grampositive organisms: clinical relevance and implications for infection control," The Journal of Hospital Infection, vol. 42, no. 4, pp. 275-282, 1999.

[44] I. Al Kassaa, M. Hamze, D. Hober, N.-E. Chihib, and D. Drider, "Identification of vaginal lactobacilli with potential probiotic properties isolated from women in North Lebanon.," Microbial Ecology, vol. 67, no. 3, pp. 722-734, 2014.

[45] V. Abramov, V. Khlebnikov, I. Kosarev et al., "Probiotic properties of lactobacillus crispatus 2,029: homeostatic interaction with cervicovaginal epithelial cells and antagonistic activity to genitourinary pathogens," Probiotics and Antimicrobial Proteins, vol. 6, no. 3-4, pp. 165-176, 2014.

[46] M. S. Carmo, F. M. Noronha, M. O. Arruda et al., "Lactobacillus fermentum ATCC 23271 Displays In vitro Inhibitory Activities against Candida spp.," Frontiers in Microbiology, vol. 7, 2016.

[47] S. Kim, W. M. Lee, K. S. Park, J. B. Kim, D. J. Han, and J. Bae, "The effect of Lactobacillus casei extract on cervical cancer cell lines," Wspótczesna Onkologia, vol. 4, pp. 306-312, 2015.

[48] B. Henrich, F. Kretzmer, R. Deenen, K. Köhrer, and M. F. Balish, "Validation of a novel Mho microarray for a comprehensive characterisation of the Mycoplasma hominis action in HeLa cell infection," PLoS ONE, vol. 12, no. 7, p. e0181383, 2017.

[49] M. Hopfe, R. Deenen, D. Degrandi, K. Köhrer, and B. Henrich, "Host cell responses to persistent mycoplasmas - different stages in infection of hela cells with mycoplasma hominis," PLoS ONE, vol. 8, no. 1, Article ID e54219, 2013.

[50] X. You and W. U. Zeng, "Interations between lipid-associated membrane proteins and host cells," Journal of Zhejiang Universit, vol. 7, pp. 342-350, 2008.

[51] Y. Zeng, Y. Wu, Z. Deng et al., "Apoptosis induced by lipidassociated membrane proteins from Mycoplasma penetrans is mediated by nuclear factor kappaB activation in mouse macrophage," Canadian Journal of Microbiology, vol. 54, no. 2, pp. 150-158, 2008.

[52] T. Into, Y. Nodasaka, A. Hasebe et al., "Mycoplasmal lipoproteins induce Toll-like receptor 2- and caspases-mediated cell death in lymphocytes and monocytes," Microbiology and Immunology, vol. 46, no. 4, pp. 265-276, 2002.

[53] L. Siroli, F. Patrignani, D. I. Serrazanetti et al., "Determination of antibacterial and technological properties of vaginal lactobacilli for their potential application in dairy products," Frontiers in Microbiology, vol. 8, 2017.

[54] T. Prince, A. J. McBain, and C. A. O’Neill, "Lactobacillus reuteri protects epidermal keratinocytes from Staphylococcus aureus-induced cell death by competitive exclusion," Applied and Environmental Microbiology, vol. 78, no. 15, pp. 5119-5126, 2012.

[55] M. Daniele, F. Ruiz, L. Pascual, and L. Barberis, "Ureaplasma urealyticum and mycoplasma hominis sensitivity to bacteriocins produced by two lactobacilli strains," Current Microbiology, vol. 63, no. 4, pp. 360-365, 2011. 


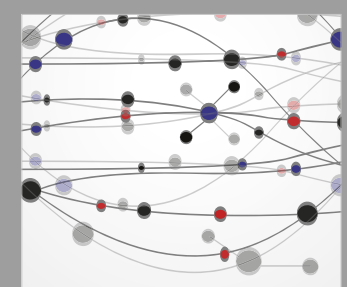

The Scientific World Journal
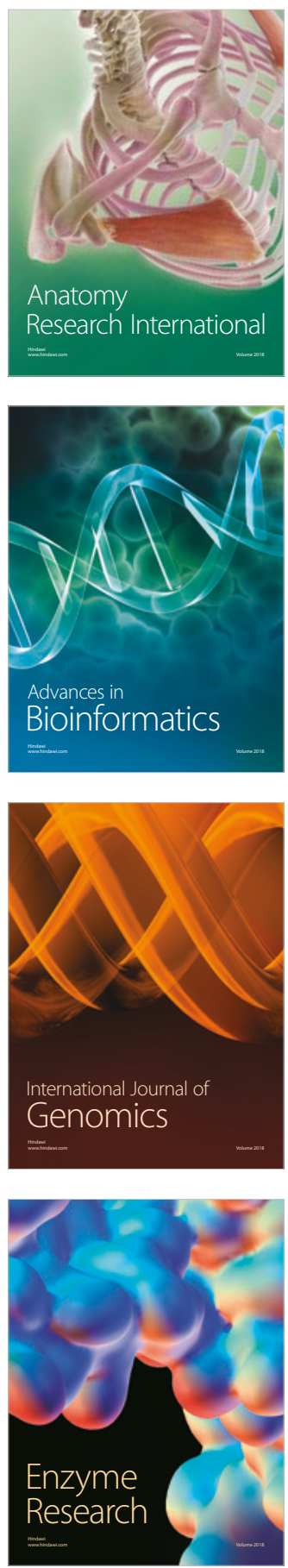
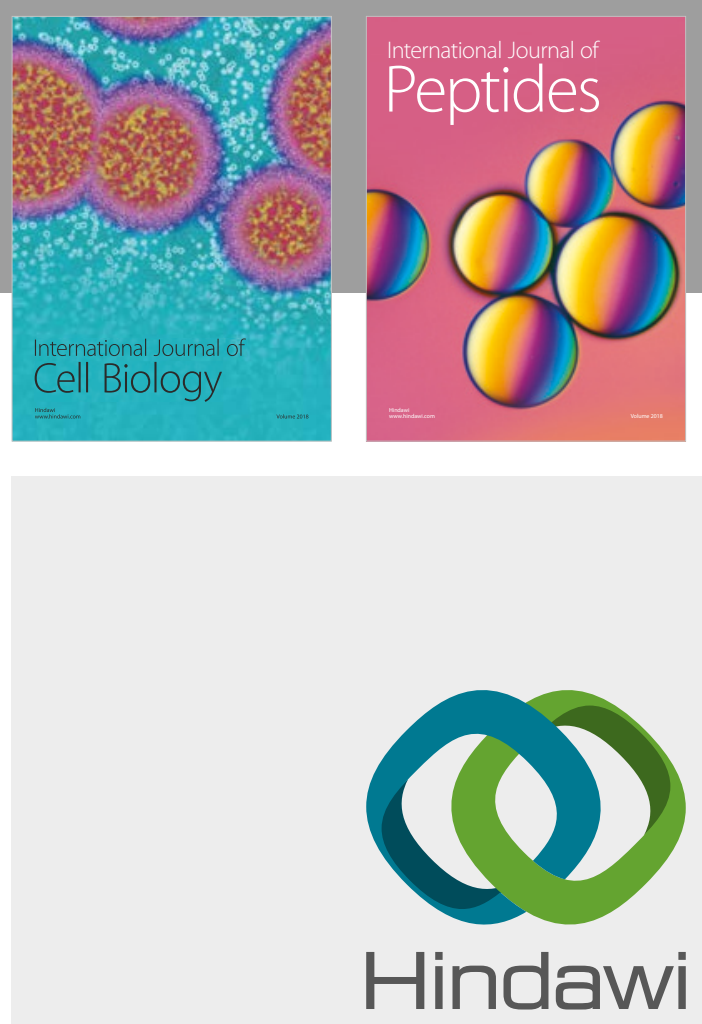

Submit your manuscripts at

www.hindawi.com
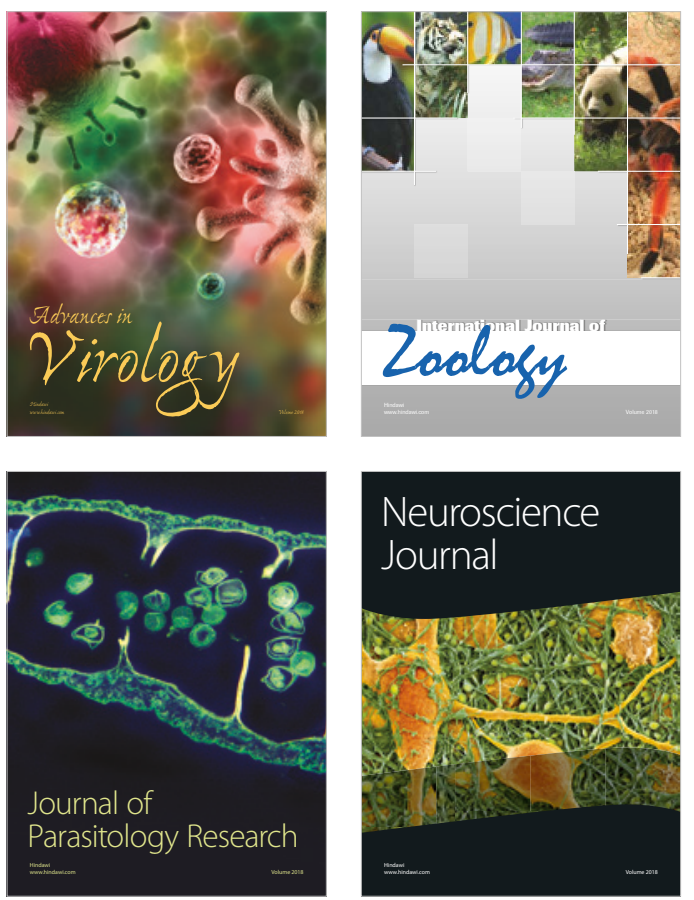
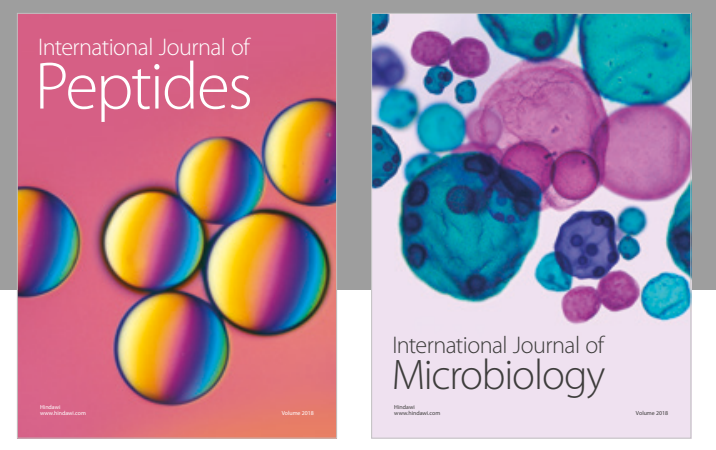

nternational Journal of Microbiology
Journal of
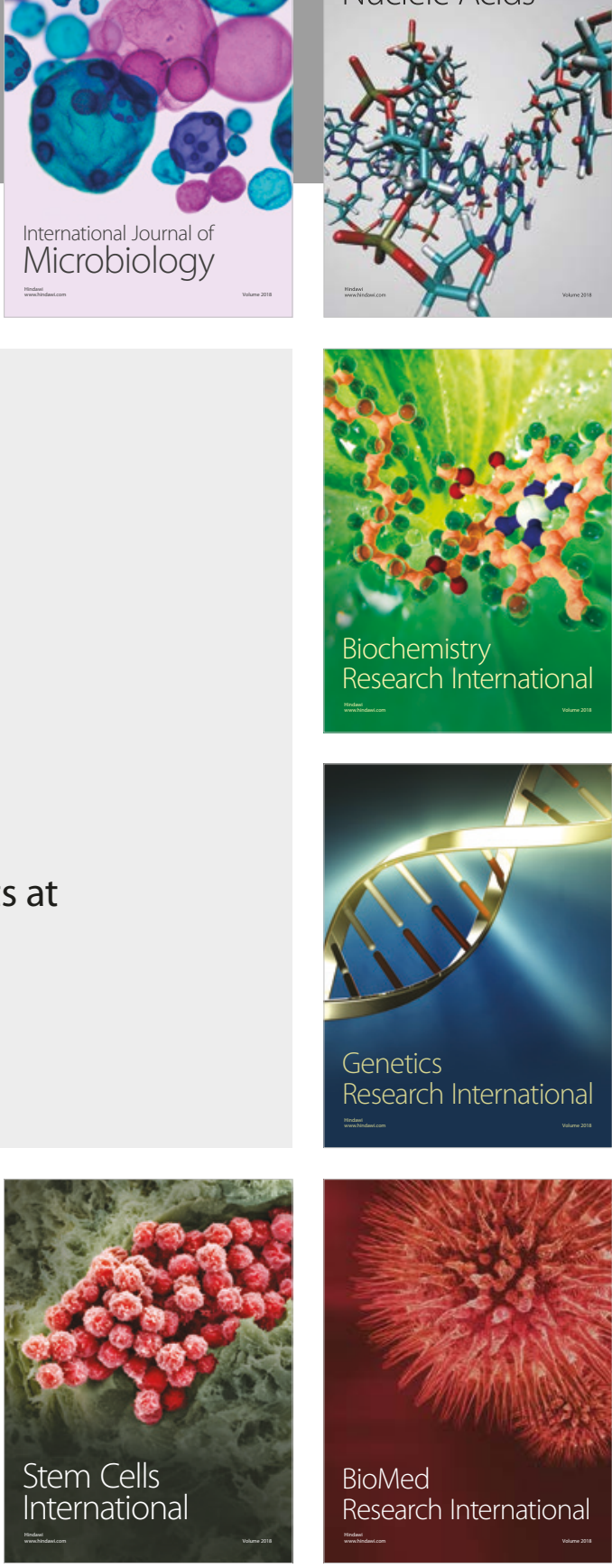
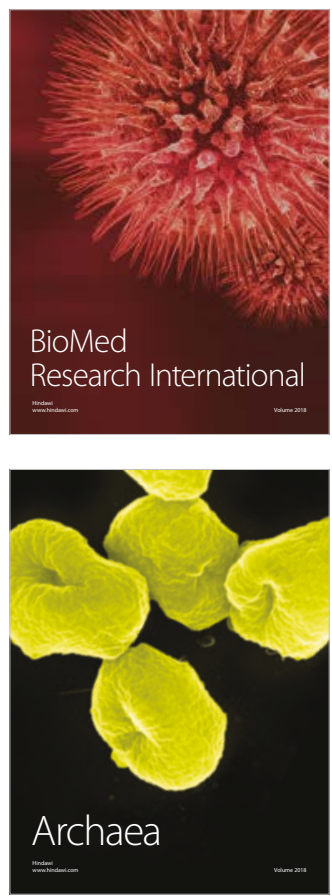